\title{
Loss of foundation species increases population growth of exotic forbs in sagebrush steppe
}

\author{
Janet S. Prevéy, Matthew J. Germino, ${ }^{1}$ and Nancy J. Huntly ${ }^{2}$ \\ Department of Biological Sciences, Mail Stop 8007, Idaho State University, Pocatello, Idaho 83209 USA
}

\begin{abstract}
The invasion and spread of exotic plants following land disturbance threatens semiarid ecosystems. In sagebrush steppe, soil water is scarce and is partitioned between deeprooted perennial shrubs and shallower-rooted native forbs and grasses. Disturbances commonly remove shrubs, leaving grass-dominated communities, and may allow for the exploitation of water resources by the many species of invasive, tap-rooted forbs that are increasingly successful in this habitat. We hypothesized that exotic forb populations would benefit from increased soil water made available by removal of sagebrush, a foundation species capable of deep-rooting, in semiarid shrub-steppe ecosystems. To test this hypothesis, we used periodic matrix models to examine effects of experimental manipulations of soil water on population growth of two exotic forb species, Tragopogon dubius and Lactuca serriola, in sagebrush steppe of southern Idaho, USA. We used elasticity analyses to examine which stages in the life cycle of $T$. dubius and L. serriola had the largest relative influence on population growth. We studied the demography of T. dubius and L. serriola in three treatments: (1) control, in which vegetation was not disturbed, (2) shrubs removed, or (3) shrubs removed but winter-spring recharge of deep-soil water blocked by rainout shelters. The short-term population growth rate $(\lambda)$ of $T$. dubius in the shrub-removal treatment was more than double that of T. dubius in either sheltered or control treatments, both of which had limited soil water. All $L$. serriola individuals that emerged in undisturbed sagebrush plots died, whereas $\lambda$ of $L$. serriola was high $(\lambda>2.5)$ in all shrub-removal plots, whether they had rainout shelters or not. Population growth of both forbs in all treatments was most responsive to flowering and seed production, which are life stages that should be particularly reliant on deep-soil water, as well as seedling establishment, which is important to most plant populations, especially during invasion. These data indicate the importance of native species, in this case the dominant shrub, in influencing soil resources and restricting population growth of exotic plants. These results argue that management of invasive plants should focus not only on removal of nonnatives, but also on reestablishment of important native species.
\end{abstract}

Key words: Artemisia tridentata; community invasibility; invasive plants; Lactuca serriola; plant-soil water relation; population matrix modeling; sagebrush steppe; Tragopogon dubius.

\section{INTRODUCTION}

Semiarid ecosystems, such as sagebrush steppe, are particularly susceptible to disturbance and invasion by exotic species (Holmgren et al. 2006, Maestre et al. 2006, Chambers and Wisdom 2009). Invasive plants often proliferate, persist, and become dominant after disturbances (D’Antonio and Vitousek 1992, Stylinski and Allen 1999, D'Antonio 2000, Keeley 2006, Kulmatiski 2006). How the presence or absence of dominant native plants relates to the success of invaders is a major question for the ecology and management of invasive species. A possible explanation for the success of exotic plants after disturbances may be that they capitalize on

Manuscript received 29 April 2009; revised 13 October 2009; accepted 10 November 2009; final version received 22 December 2009. Corresponding Editor: J. Belnap.

${ }^{1}$ Corresponding author. E-mail: germmatt@isu.edu

2 Present address: National Science Foundation, 4201 Wilson Boulevard, Arlington, Virginia 22201 USA. an increase in available resources, such as soil water, that previously were used by native species.

Single plant species can influence much of the community structure in some ecosystems by "creating locally stable conditions for other species, and by modulating and stabilizing fundamental ecosystem processes" such as productivity and hydrology, and are thus referred to as a foundation species (Ellison et al. 2005). Species identified as ecosystem engineers or as dominant, core, keystone, or structural species all share some attributes of foundation species (Ellison et al. 2005). Loss of foundation species can have substantive and disproportionate effects on co-occurring organisms and ecosystem processes and stability, as shown for American chestnut and whitebark pine (Ellison et al. 2005). It follows that loss of foundation species could also increase community invasibility.

In the semiarid shrub steppe of southern Idaho, sagebrush is likely a foundation species. Sagebrush is locally abundant and widespread throughout Great 
Basin cold desert ecosystems and uses both shallow- and deep-soil water. The shrub has a relatively tall and broad crown (compared to surrounding herbs) with semievergreen foliage having volatile and organic compounds known to affect surrounding soil biota, plants, and animals (Karban 2007 and reviews in Dobrowolski et al. 1990, Smith et al. 1997). Sagebrush structures the plant and animal communities around it (Welch 2005), as indicated by reductions of key native herbs, generalist herbivores, and birds (e.g., Greater Sage Grouse) upon loss of sagebrush (Leonard et al. 2000, Karban 2007, Prevéy et al. 2010). Past management practices, increased frequency of wildfire, and conversion of sagebrush steppe to cropland have resulted in the elimination of sagebrush from much of its former range and a corresponding increase in invasive exotic herbs (Whisenant 1990, Noss et al. 1995, Davies et al. 2009). The loss of sagebrush could increase resource availability to the advantage of exotic invaders. The increase in available soil resources following shrub removal via mowing or tebuthiuron application is/has been the rationale for several range management treatments designed to increase perennial herbaceous grasses and forbs in sagebrush ecosystems. The risk in using these treatments is an increase in annual grasses and weedy forbs (Monsen et al. 2004). Fire is the major disturbance resulting in sagebrush removal, and growth and seed production in Bromus tectorum increased substantially after fire (Chambers et al. 2007).

Water is a primary limiting resource in semiarid regions (Noy-Meir 1973, Hadley and Szarek 1981) such as sagebrush steppe (Caldwell 1985). In cold deserts, the majority of annual precipitation is received in the winter and early spring, when plants are dormant (Caldwell 1985). Winter precipitation can thus infiltrate deeper soil layers and is used by deep-rooted shrubs during the dry summer months (Smith et al. 1997). Accordingly, removal of sagebrush increases available moisture of deeper soils during the growing season whereas uptake by herbaceous species minimizes increases in available water in shallower soils $(0-30 \mathrm{~cm})$ after fire or shrub removal (Cook and Lewis 1963, Sturges 1973, Inouye 2006, Chambers et al. 2007).

The invasibility of an ecosystem has been linked to availability of resources (Davis et al. 2000, Shea and Chesson 2002, Daehler 2003). Because shrubs use more soil water than native grasses and herbs alone (Cook and Lewis 1963, Sturges 1973, Inouye 2006), soil water that becomes available after shrub removal may fuel the invasion of exotic forbs. Many native grasses have relatively shallow root systems compared with sagebrush (Dobrowolski et al. 1990), and exotic forbs may have access to more soil water than grasses after sagebrush is eliminated. Abundances of deuterium and ${ }^{18}$ oxygen in xylem water suggest that exotic forbs such as Centaurea diffusa, like sagebrush and other shrubs, can use water from deeper soils than do grasses (Kulmatiski et al. 2006). Many exotic forbs have similar physiologies to $C$. diffusa and may also benefit from additional soil water after disturbances in semiarid environments.

Exotic plant invasions are a population growth phenomenon. We previously reported that removal of sagebrush was followed by significant increases in the density of exotic forbs (Prevéy et al. 2010). Here we report on the detailed demography of exotic forbs and the population growth rates that result when shrubs are removed from sagebrush steppe, with and without associated changes in soil water. If availability of soil water contributes to success of exotic forbs, then their population growth should increase with soil water and with shrub removal, unless shrub removal is accompanied by experimental blocking of soil water recharge in winter and early spring.

Matrix population models are used to estimate rates of population growth based on patterns of survivorship and fecundity (Werner and Caswell 1977, Caswell 2001). Matrix models can project population growth under different conditions and can identify the stages in the life cycle that most affect population growth. Matrix modeling approaches have been used to compare population growth and the influence of different life stages on population growth of invasive plants in different habitats (Werner and Caswell 1977, Parker 2000), or in response to biocontrol strategies (Shea and Kelly 1998, Davis et al. 2006) and other management practices (Emery and Gross 2005, Pardini et al. 2009). We used matrix modeling to assess the effects of experimental removal of foundation species and subsequent increases in soil resources on the population growth of exotic plants.

We tested the hypothesis that invasive forb populations would benefit from increased soil water made available by the loss of sagebrush in semiarid shrubsteppe ecosystems by examining the effects of shrub removal and associated increases in soil water on the population growth of two exotic forb species, Tragopogon dubius and Lactuca serriola, in a sagebrush-steppe ecosystem. These species are subject to considerable herbivory by both insects and mammals in their invaded range (Reichman and Smith 1991), so enemy-release hypotheses are unlikely to explain their success. We predicted that: (1) population growth rates of $T$. dubius and L. serriola would increase following experimental shrub removal, except where winter and early spring precipitation was blocked to prevent soil moisture increase, and (2) flowering and seed production would have the largest contributions to population growth, especially with the increases in soil water that accompany sagebrush removal that should alleviate the seasonal drought that prevails when these forbs flower.

\section{Methods \\ Study site}

We studied the demography of Tragopogon dubius and Lactuca serriola from plots at the Idaho State University (ISU) Barton Road Ecological Research 
Area in Pocatello, Idaho, USA, located east of the ISU campus along Barton Road, Bannock County (42.853 ${ }^{\circ}$ $\left.\mathrm{N}, 112.402^{\circ} \mathrm{W}, \sim 1460 \mathrm{~m}\right)$. The area was designated as a research site in 1996 and had probably not been grazed for several decades, based on relatively high abundance of biotic crusts. The area was likely subject to heavy sheep grazing in the early 1900s. The site is sagebrush steppe, dominated by the shrub Artemisia tridentata (big sagebrush, mainly subspecies $A$. t. tridentata, with some A. $t$. wyomingensis), with trace amounts of the shrubs Chrysothamnus nauseosus, C. viscidiflorus, Atriplex canescens, and Eurotia lanata. Most sagebrush were younger than 40 years old, possibly indicating a fire before that time. Grasses common to the site are Bromus tectorum, Poa bulbosa, Agropyron cristatum, Stipa comata, and Agropyron dasytachum. Common native forbs include Erigeron spp., Phlox hoodii, Calochortus nuttallii, Zigadenus venenosus, and Castilleja spp. Exotic forbs include Tragopogon dubius, Lactuca serriola, Sisymbrium altissimum, and Melilotus officinalis. Plant taxonomy follows Hitchcock and Cronquist (1973).

All plots were located within a 3-ha area with a westfacing aspect and an average slope of $10^{\circ}$. Soils in the area are fine-grained calcareous silt loams (McGrath 1987). Mean annual precipitation is $\sim 32 \mathrm{~cm}$, although during the course of the study, average yearly precipitation was only $25 \mathrm{~cm}$ (National Climatic Data Center; available online $)^{3}$

\section{Treatments}

We examined effects of sagebrush and soil water on the population growth of T. dubius and L. serriola from three experimental treatments assigned to six blocks in a randomized complete-block design within the research area (Prevéy et al. 2010). In October-November 2006, we applied the treatments to $9 \times 11.5 \mathrm{~m}$ plots within each block, for a total of 18 plots. The control treatment was undisturbed, and although blocks differed slightly in relative abundance of sagebrush and herb species, we ensured that there were no significant pretreatment differences in sagebrush or exotic or native forbs. Some plot area in two of the six blocks was drill-seeded decades earlier with $A$. cristatum. The shrub-removal treatment had all shrubs cut at the base of the stem and removed, but was otherwise undisturbed. The majority of shrubs were Artemisia tridentata (98\%), but smaller numbers of Chrysothamnus spp. (2\%) were also removed. The sheltered treatment had all shrubs cut and removed, and plots were entirely covered with a clear polyethylene plastic shelter from November through April that selectively blocked the winter precipitation that contributes to deep-soil water (Prevéy et al. 2010). Any rainout shelter has climate artifacts, but the design used here did not alter average air or soil-surface temperatures, and caused only a $1.5^{\circ} \mathrm{C}$

\footnotetext{
${ }^{3}\langle$ http://lwf.ncdc.noaa.gov/oa/ncdc.html $\rangle$
}

warming of soils at $10 \mathrm{~cm}$ depth in soil during the dormant season (Prevéy et al. 2010). This shelter treatment allowed us to examine effects of shrub removal without accompanying increases in soil water.

To provide information on community change as context for our emphasis on exotic forb populations, we measured canopy cover of shrubs, bunchgrasses, exotic forbs, and also bare soil in the plots. We used a linepoint intercept method on six sampling dates that ranged from the summer before treatments were applied in 2006 to summer 2009, which was after the termination of our population modeling and use of rainout shelters in 2008. We recorded the cover intersected by pins held in a nadir position, at 160 points per plot. Points were located at 1-m intervals along 20 transects, and transects were positioned at $0.5-\mathrm{m}$ intervals along the southern boundary of each plot and were oriented toward the northern boundary. We excluded the area in the outer 1 $\mathrm{m}$ of each plot from our sampling. To determine the significance of changes in bunchgrass and exotic forb cover among the treatments, we used a mixed-model ANOVA (PROC MIXED) with repeated-measures and Tukey's hsd tests (SAS 9.1.3; SAS Institute 2002-2003). Treatment and sampling date (time) were fixed effects, and block was a random effect. Because control plots were not sampled in November 2007, data from this date were not included in the mixed-model ANOVA.

We used a neutron probe (model 503DR Hydroprobe, California Pacific Nuclear, Martinez, California, USA) to measure soil water content in the plots throughout the summer. We inserted two $2 \mathrm{~m}$ long aluminum access tubes vertically in central locations within each plot. The tubes were $\sim 4 \mathrm{~m}$ from either edge of the plot and $2 \mathrm{~m}$ from each other. The neutron probe was used to measure soil moisture at $20-\mathrm{cm}$ intervals from 20 to $180 \mathrm{~cm}$ below the soil surface. Count data from the neutron probe were converted to volumetric water content (Prevéy et al. 2010). Soil-moisture measurements were taken at two-week intervals during the growing seasons (13 April-20 August) of 2007 and 2008 to verify that the treatments were leading to different amounts of soil water. We used repeated-measures ANOVAs (RMANOVAs) and Tukey's hsd tests to analyze differences in average soil water from 20 to $80 \mathrm{~cm}$ depths between the treatments, and within each treatment, over the course of the growing season. We did not include analysis of soil water $>80 \mathrm{~cm}$ depth because all treatments had similar soil moisture below that depth (all $F_{2,10}<1, P>0.9$ ), and soil moisture recharge and depletion were negligible $>80 \mathrm{~cm}$ in 2007 and 2008. We analyzed 2007 and 2008 separately due to large differences in winter precipitation. ${ }^{3}$ When assumptions of sphericity were violated, we used Wilks' lambda statistics for within-subjects tests of changes in soil water over time in the different treatments. More detailed depth-resolved analyses of these data are reported in Prevéy et al. (2010). 


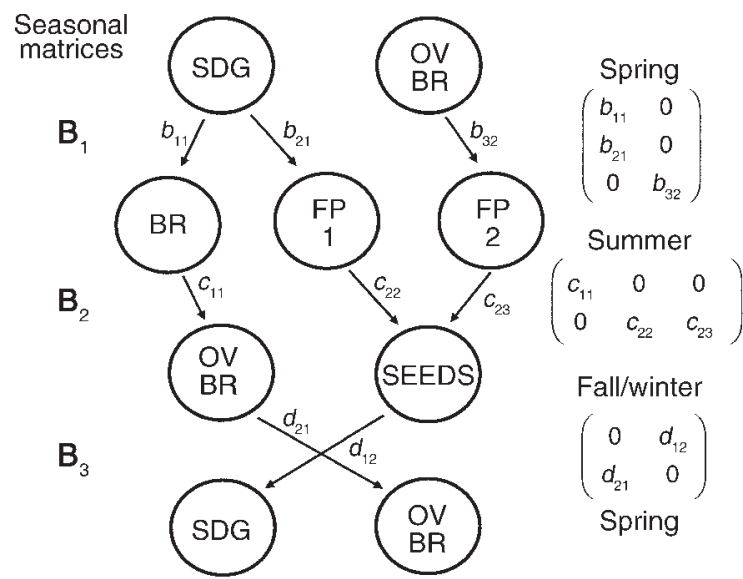

FIG. 1. A life cycle graph for the exotic forb Tragopogon dubius from plots at the Idaho State University (ISU) Barton Road Ecological Research Area in Pocatello, Idaho, USA. Each row corresponds to a season in the year, and each circle represents a stage in the plant's life cycle (Key to abbreviations: SDG, seedling; OV BR, overwintering basal rosette; BR, basal rosette; FP 1, flowering plant from seedling; FP 2, flowering plant from overwintering basal rosette). Straight arrows indicate advancement from one stage to another. The transition probabilities by the arrows (e.g., $b_{11}, b_{12}$ ) represent the probabilities of individuals advancing to other stages.

\section{Subject species}

Tragopogon dubius and Lactuca serriola (Asteraceae) are introduced monocarpic forbs that are native to Eurasia, but are now widespread throughout the United States and Canada and are considered invasive in many parts of their introduced range (Whitson 2000, USDA NRCS 2008). T. dubius commonly grows as a biennial, but can be annual or perennial (USDA NRCS 2008). $T$. dubius can grow to $30-100 \mathrm{~cm}$ tall, with long taproots and multiple branches terminating in yellow flowers (Clements et al. 1999). L. serriola grows as a summer annual that germinates in the spring and reproduces over the summer, or as a winter annual that germinates in the fall, overwinters as a rosette, and reproduces the following year (Prince et al. 1978). L. serriola can be 0.5 to $>1.5 \mathrm{~m}$ tall in sun-exposed locations (Weaver and Downs 2003) and can grow long tap roots (e.g., to $58 \mathrm{~cm}$ within 5 weeks of germination; Jackson 1995). Both $T$. dubius and $L$. serriola reproduce solely by seed (Whitson 2000). T. dubius can have 1-14 seed heads and produce 20-127 wind-dispersed seeds per head (McGinley 1989), and $L$. serriola produces numerous small flowers in heads that have 10-30 wind-dispersed seeds in mid- to late summer (Weaver and Downs 2003).

\section{Matrix model construction}

We created periodic matrix models that were classified by life stage for $T$. dubius and L. serriola growing in the three treatments. We chose periodic matrix models (multiple time steps/year) because we wanted to examine seasonal transitions in the life cycle of the plant that would be masked in annual transition matrix models (i.e., one time step/year; Caswell 2001). We used stageclassified models because stage (size and developmental status) is often a better indicator of plant fate than age (Harper 1977, Werner and Caswell 1977). Periodic matrix models were constructed following the methods of Caswell (2001: Section 13.2) and Smith et al. (2005). The models used seasonal phases based on the life stages of individual T. dubius and L. serriola plants at different times in the year (Figs. 1 and 2).

Phases were identified after observing the phenology of $T$. dubius and L. serriola in summer 2007. For $T$. dubius, three phases were identified: spring (April to mid-June), summer (mid-June to August), and fallwinter (September to March; Fig. 1). Seedlings emerged in spring, and then became basal rosettes or flowering plants in summer. Plants that remained as basal rosettes in the summer overwintered as rosettes through the fall and winter and flowered the following year. Plants that flowered in their first summer produced seeds and died in the fall and winter (Fig. 1).

For L. serriola, four phases were identified: spring (April-mid-June), summer (mid-June-September), fall (October-November), and winter (December-March; Fig. 2). Models of L. serriola included an additional phase because many seedlings emerged in the winter. Seedlings germinating in spring became small $(<50 \mathrm{~cm}$ height) or large ( $>50 \mathrm{~cm}$ height) flowering plants during

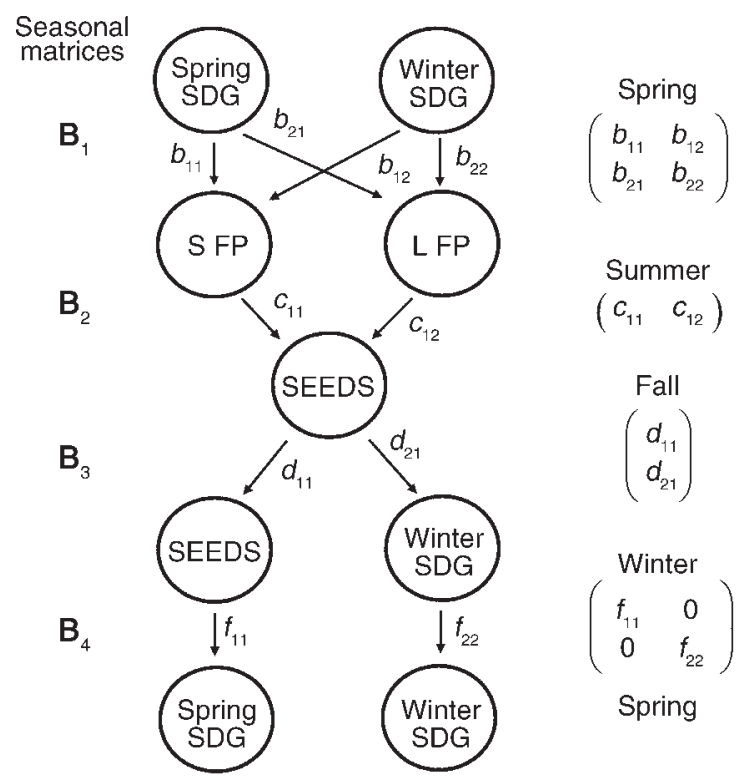

FIG. 2. A life cycle graph for the exotic forb Lactuca serriola. Each row corresponds to a season in the year, and each circle represents a stage in the plant's life cycle (Key to abbreviations: Spring SDG, seedling germinating in spring; Winter SDG, seedling germinating in winter; S FP, small flowering plant; L FP, large flowering plant). Arrows indicate advancement from one stage to another. The transition probabilities by the arrows (e.g., $b_{11}, b_{12}$ ) represent the probabilities of individuals advancing to other stages. 
summer and produced seeds in the fall. These seeds emerged in winter, overwintered as seedlings, and became small or large flowering plants the following summer or remained dormant as seeds and emerged the following spring (Fig. 2). The life histories of plants growing in each treatment were used to construct seasonal matrices (Figs. 1 and 2). Seasonal matrices $\left(\mathbf{B}_{\mathrm{i}}\right)$ were developed for each phase, with elements $\left(a_{i j}\right)$ corresponding to probabilities of progressing from one stage to the next (i.e., transition probabilities). Transitions between phases correspond to seasonal matrices $\mathbf{B}_{1}, \mathbf{B}_{2}$, and $\mathbf{B}_{3}$ for $T$. dubius (Fig. 1) and matrices $\mathbf{B}_{1}, \mathbf{B}_{2}, \mathbf{B}_{3}$ and $\mathbf{B}_{4}$ for L. serriola (Fig. 2). To measure the yearly rates of population growth $(\lambda)$, the seasonal matrices were multiplied to give an annual matrix, A. For example, to measure the annual rate of population growth $(\lambda)$ of $T$. dubius starting in the spring $\left(\mathbf{B}_{1}\right)$, the seasonal matrices were multiplied to give their periodic product:

$$
\mathbf{A}_{1}=\mathbf{B}_{3} \mathbf{B}_{2} \mathbf{B}_{1} .
$$

The population growth rate $(\lambda)$ per yearly cycle is given by the dominant eigenvalue of $\mathbf{A}_{1}$. All three annual matrices $\left(\mathbf{A}_{1}, \mathbf{A}_{2}\right.$, or $\left.\mathbf{A}_{3}\right)$ give the same rates of population growth $(\lambda)$, independent of the season in which the projection starts $\left(\mathbf{B}_{1}, \mathbf{B}_{2}\right.$, or $\left.\mathbf{B}_{3}\right)$.

\section{Model parameterization}

Data on T. dubius and L. serriola populations were collected during 2007 and 2008 in six plots of each treatment type. Periodic matrix models were created from the pooled data of individual plants in all six plots of each treatment. This method ensured that plots with few individuals were not overrepresented in calculations of vital rates (Horvitz and Schemske 1995, Lucas et al. 2008), and population sizes were small in some plots.

To determine percentage emergence during the spring, we spread $30 \mathrm{~T}$. dubius seeds and $50 \mathrm{~L}$. serriola seeds onto the soil surface of a $1-\mathrm{m}^{2}$ subplot in the center of each plot, with each species seeded onto half of the subplot area. Seeding was done on 13 February 2008, and the subplot was covered with a thin layer of soil. We found seed fill to be $100 \%$ in several other seed collections at this site. In sagebrush plots, the subplots were located in open areas between sagebrush canopies to reduce the effects of canopy cover on seedling emergence (Marks and Prince 1982). Beginning 25 April 2008, we monitored the subplots every two days and marked all seedlings that emerged for several months, until soil surfaces were dry and emergence had ceased for the season. After one month, all seedlings were removed and the total number of emergents per plot was recorded. Probabilities of emergence were calculated by dividing the number of seeds that emerged by the total number of seeds planted in each treatment type. A seedbank was not included in the model because $T$. dubius and $L$. serriola do not form persistent seedbanks ( $<1-2$ years; Gross and Werner 1982,
Marks and Prince 1982, Meiqin and Upadhyaya 1993 , Weaver and Downs 2003).

To determine the number of individuals within the different stages of $T$. dubius and L. serriola populations emerging in the plots, we marked all individuals of these species and monitored their phenology and reproduction at two-week intervals throughout the growing season. Stages identified for $T$. dubius were seedling (SDG), basal rosette (BR), flowering plant from seedling (FP 1), flowering plant from overwintering basal rosette (FP 2), and overwintering rosette (OV BR; Fig. 1). In the late summer and early fall, we counted the number of seed heads and seeds on each T. dubius plant. In late fall 2007 , large basal rosettes that had not yet senesced were identified as overwintering rosettes and monitored the following spring and summer to calculate probabilities for survival to the flowering stage. Because T. dubius was scarce in control plots in 2007 and 2008, additional individuals were marked up to $20 \mathrm{~m}$ away from established control plots. These plants were located in contiguous sagebrush similar to that inside the plot and were no more than $0.5 \mathrm{~m}$ away from a shrub. Over the two study years, 114 seedlings were marked and followed in (or near) control plots, 209 seedlings were marked in shrub-removal plots, and 104 seedlings were marked in shelter plots.

Stages identified for L. serriola were: seedling germinating in spring (spring SDG), seedling germinating in winter (winter SDG), small flowering plant (S FP), and large flowering plant (L FP; Fig. 2). During the study period, only $10 \mathrm{~L}$. serriola seedlings emerged in control plots, and none survived past the seedling stage, so matrix models were constructed only for shrub-removal and sheltered treatments. Because mortality of marked seedlings was high, we arbitrarily chose additional, representative $L$. serriola flowering plants from shrubremoval and sheltered plots in late summer 2008 and counted their seed production to increase the accuracy of fecundity calculations. To minimize the time demands required to count all seeds on every $L$. serriola plant, we estimated the average number of seeds per head by counting the number of seeds per flower head for a subsample of 10 seed heads on each of five randomly chosen plants in each treatment type. The number of seeds per head was similar for plants from both treatments (shrub removal, $18.47 \pm 0.45$ seeds, mean $\pm \mathrm{SE}$; sheltered, $18.13 \pm 0.42$ seeds, $F_{1,9}=0.96, P=$ 0.36 ) so we used the average number of seeds per head (18 seeds) multiplied by the number of seed heads on each plant to give total seed output per plant.

We estimated overwinter seedling survival by counting and marking all late-fall emergents in shrubremoval, sheltered, and control plots in November 2007, and recounted surviving overwintering seedlings in the same plots in April 2008. In November 2007, a total of $2186 \mathrm{~L}$. serriola seedlings were counted in shrubremoval plots, 1174 seedlings in sheltered plots, and 0 seedlings in control plots. In April 2008, 355 overwin- 


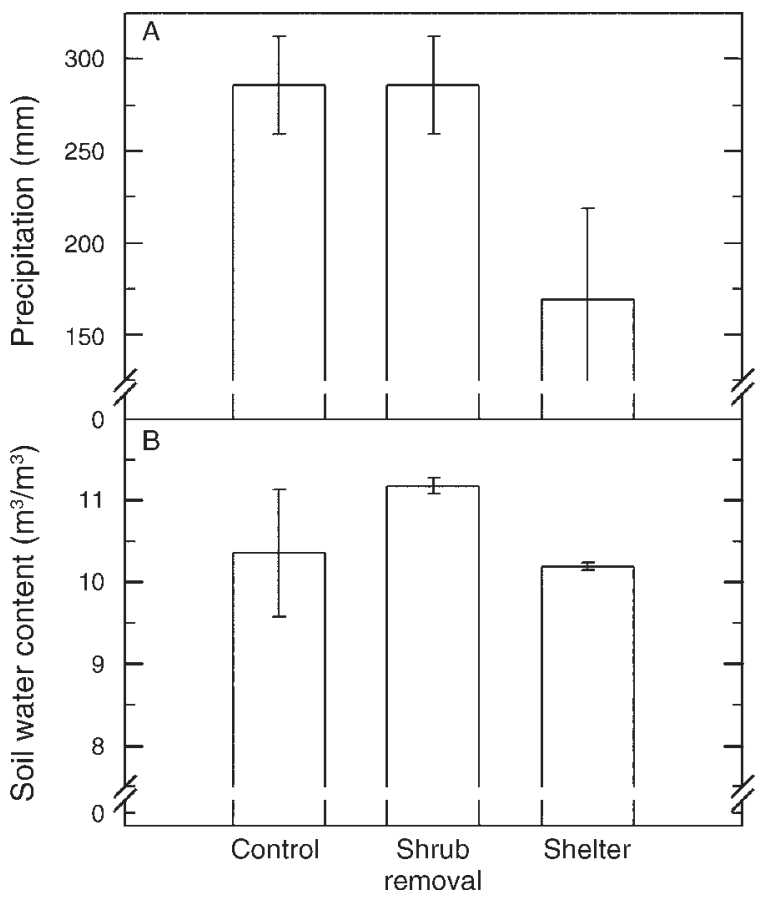

FIG. 3. (A) Total average yearly precipitation received by control, shrub-removal, and sheltered plots in 2007 and 2008 (mean of two years \pm SE) and (B) average soil water content from 20 to $80 \mathrm{~cm}$ depth during the growing season, 10 May-20 August in 2007 and 2008. Precipitation data were collected at the Pocatello $2 \mathrm{NE}$ reporting station located $\sim 6 \mathrm{~km}$ from the ISU Ecological Research Area, Pocatello, Idaho, USA (regression of Pocatello $2 \mathrm{NE}$ station vs. ISU research area precipitation data; $r^{2}=0.98$ ).

tering seedlings survived in shrub-removal plots, and 276 seedlings in sheltered plots; 2016 new seedlings were observed in shrub-removal plots and 1104 new seedlings were observed in sheltered plots. We assumed equal probabilities of a seed emerging in winter or spring because we could not directly measure those probabilities, and similar numbers of winter and spring seedlings were observed in each treatment.

\section{Demographic analyses}

We estimated rates of population growth in the three treatments using PopTools version 3.0.6 (Hood 2008), which uses transition matrices and matrix algebra to determine population growth from the abundance of individuals in each life stage and the probability of remaining in the life stage or progressing to the next life stage. Differences between the population growth rates of $T$. dubius and L. serriola in the three treatments were evaluated with randomization tests (500 random permutations; Caswell 2001: Section 12.3) and standard errors were calculated from bootstrap resampling of individuals in each treatment (Caswell 2001: Section 12.1.2). We used elasticity analyses for periodic matrix models to evaluate the importance of different life stages to the population growth rates, following the methods described by Caswell and Trevisan (1994) and Caswell (2001: Section 13.1.4).

To evaluate whether differences in herbivory among treatments might influence our conclusions, we recorded evidence of herbivory and compared the percentages of plants that experienced herbivory using blocked ANOVA (SAS 9.1.3, SAS Institute 2002-2003). To evaluate whether seed predation, which we did not measure, would be likely to change the conclusions of our study, we calculated the percentage of seeds that would have to be removed by predators to decrease population growth rates below one.

\section{Results}

\section{Soil moisture and community cover}

Yearly precipitation averaged $254 \mathrm{~mm}$ over the study period (October 2006-September 2008; Fig. 3). Shelters, which covered plots from November to April, blocked $94 \mathrm{~mm}$ precipitation in 2006-2007 and $139 \mathrm{~mm}$ precipitation in 2007-2008 (Fig. 3).

In the summer of 2007, soil water was greater in shrub-removal plots compared with sheltered and control plots during most of the growing season, between 27 April 2007 and 2 July 2007 (RM-ANOVA, $F_{2,10}=13.79, P=0.0013$, Tukey's $P<0.05$; Table 1, Fig. $4)$. Thereafter, in 2007 , soil water was least abundant in control plots (Tukey's $P<0.05$ ). The rate of soil water depletion in control plots was greater than that of shrubremoval and sheltered treatments (Fig. 4) In the summer of 2008, shrub-removal and control plots had more soil water than sheltered plots (RM-ANOVA, $F_{2,10}=5.12, P$ $=0.03$, Tukey's $P<0.05$; Fig. 4), although this difference only lasted from 20 April through 15 June 2008, after which there were no differences in soil water between treatments (Tukey's $P>0.05$; Fig. 4). Over both summers, soil water was significantly depleted over time (RM-ANOVA, Wilks' lambda, 2007, $F_{7,4}=10.35$, $P=0.02 ; 2008, F_{7,4}=33.78, P=0.007$; Fig. 4). In 2007,

TABLE 1. Repeated-measures ANOVA for the comparison of soil water content between 20 and $80 \mathrm{~cm}$ depths among the experimental treatments, replicate blocks, and times of sampling of two exotic forb species, Tragopogon dubius and Lactuca serriola, in Idaho, USA, over the summers of 2007 and 2008 .

\begin{tabular}{llrl}
\hline \hline \multicolumn{1}{c}{ Year, effect } & df & $F$ & $P$ \\
\hline 2007 & & & \\
Treatment & 2,10 & 13.79 & 0.001 \\
Block & 5,10 & 1.41 & 0.30 \\
Time & 7,4 & 10.35 & 0.02 \\
Time $\times$ treatment & 14,8 & 4.24 & 0.02 \\
2008 & & & \\
Treatment & 2,10 & 5.12 & 0.03 \\
Block & 5,10 & 1.97 & 0.17 \\
Time & 8,4 & 33.78 & 0.007 \\
Time $\times$ treatment & 16,6 & 1.46 & 0.34 \\
\hline
\end{tabular}

Note: The df, $F$, and $P$ values for within-subjects effects of time and time $\times$ treatment interactions are for Wilks' lambda test statistic. 


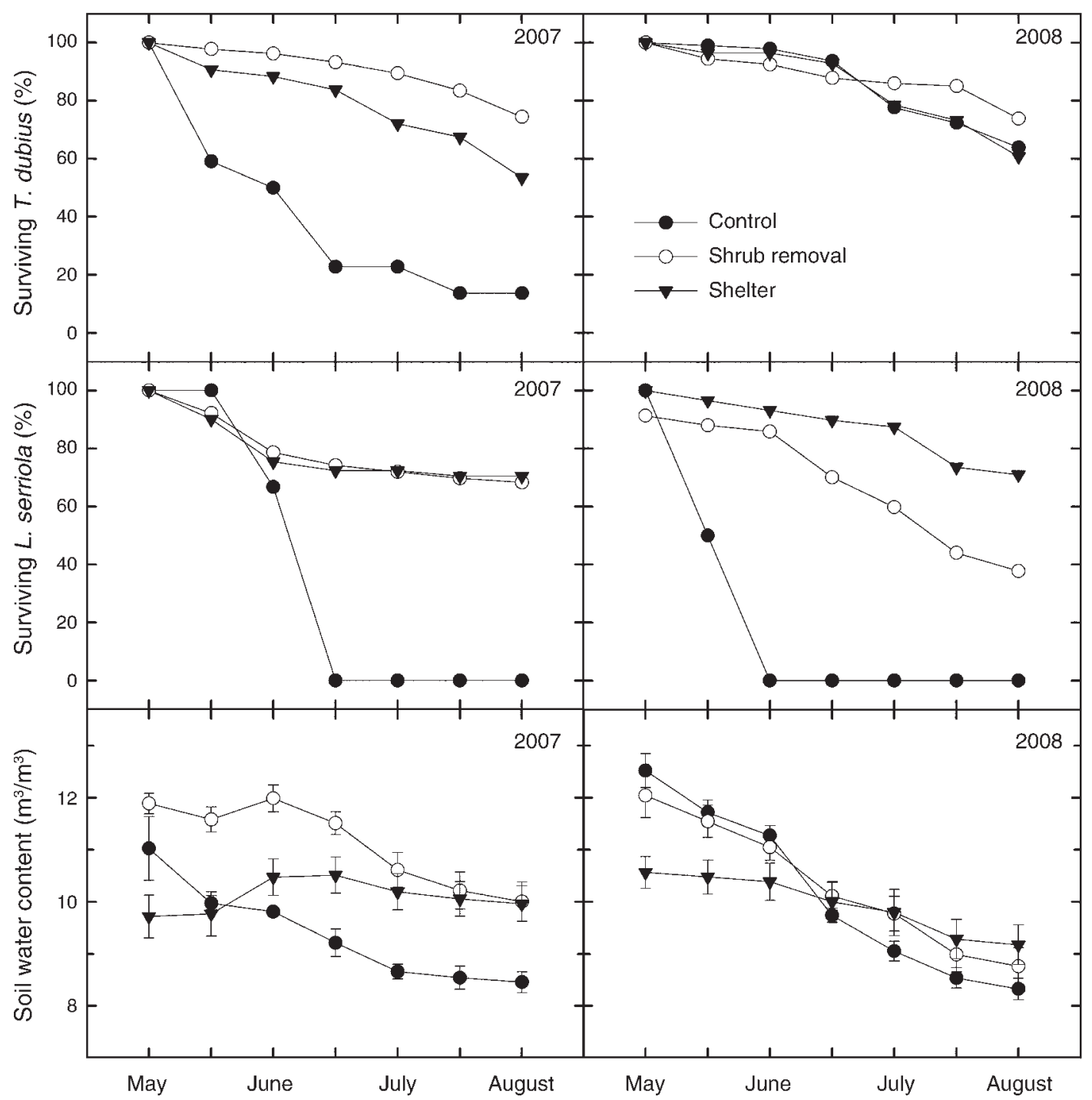

FIG. 4. Percentage of Tragopogon dubius (top panels) and Lactuca serriola (middle panels) seedlings surviving through the summers of 2007 and 2008 in control, shrub-removal, and sheltered treatments, for individuals from all blocks pooled together. The bottom panels show soil water content between 40 and $80 \mathrm{~cm}$ in control, shrub-removal, and sheltered treatments, 5 May-21 August 2007 and $2008( \pm$ SE).

the rate of soil water depletion in control plots was $30 \%$ greater than in shrub-removal and sheltered plots (Fig. 4) and, in 2008, the rate of depletion in both control and shrub-removal plots was about three times greater than in sheltered plots (Fig. 4).

Water content at $20 \mathrm{~cm}$ depth was up to $40 \%$ greater in shrub-removal and rainout-shelter plots than in control plots in 2007, but by the end of summer in 2007 and thereafter, there were no significant differences in shallow water (depth-resolved data shown in Prevéy et al. 2010). Wetting fronts in spring infiltrated the bulk soil only to $\sim 80 \mathrm{~cm}$ (similar to the longer term data of Inouye [2006]), and the water at $40-80 \mathrm{~cm}$ was less readily depleted and remained available longer in the growing season. There was $\sim 20-30 \%$ more water at $40-80 \mathrm{~cm}$ depth in shrub-removal plots than in rainout-shelter and especially in control plots until August 2007, and again in 2008 from mid-April to mid-June (Prevéy et al. 2010). Absolute differences in mean soil water contents from 100 to $180 \mathrm{~cm}$ depths ranged only from $0.1 \%\left(\mathrm{~m}^{3} / \mathrm{m}^{3}\right)$ to occasionally $0.3 \%$ among treatments over the whole study period (grand mean was $7.87 \% \mathrm{~m}^{3} / \mathrm{m}^{3}$ ).

Mean shrub cover ranged from $45 \%$ to $52 \%$ of ground area prior to treatment application, and thereafter ranged from $\sim 40 \%$ to $50 \%$ of ground area in control plots (Fig. 5). Differences in bunchgrass cover were evident only on one of the three dates in 2007 and 2008 when control plots were also measured, in which case 
bunchgrass cover was severalfold greater in plots that had sagebrush removed compared to control plots $\left(F_{4,30}\right.$ $=4.71, P=0.01$ for date $\times$ treatment interaction; $F_{2,15}=$ $0.46, P=0.64$ for main effect of treatment). In contrast, there was a substantial increase in exotic herbs with sagebrush removal, across all sampling dates $\left(F_{2,15}=\right.$ 24.0, $P<0.0001)$.

\section{Population growth rates}

$T$. dubius had the highest population growth rate in shrub-removal plots (randomization test, $P=0.002$; Fig. $6)$. There was no population growth of $T$. dubius in sheltered and control treatments (i.e., $\lambda=1$, randomization test, $P=0.6$; Table 2, Fig. 6). T. dubius was more likely to survive to the flowering stage and to flower the first year and had higher seed production in the shrubremoval plots than in control or sheltered plots.

Ten L. serriola germinants were observed in control plots over the course of the study, and they all died by early July in 2007 and 2008, so there was no population growth of L. serriola in the control treatment (Table 3, Figs. 4 and 6). Population growth rates of L. serriola were similar and high in sheltered and shrub-removal plots (randomization test, $P=0.3$; Table 3, Fig. 6).

Very few L. serriola had noticeable herbivory in any plots, but a higher percentage of $T$. dubius experienced herbivory in the sheltered plots $(39 \%)$ than in the control plots $\left(5 \%, F_{2,10}=5.22, P=0.03\right.$, Tukey's $\left.P=0.02\right)$. However, only five $T$. dubius appeared to be killed by herbivory. Seed predation of $T$. dubius in the shrubremoval plots would have had to be $>60 \%$ to decrease the population growth rate to that in the sheltered plots, and $>70 \%$ to decrease the population growth rate to $<1$. Seed predation of $L$. serriola in shrub-removal and rainout-shelter treatments would have had to be $>60 \%$ to reduce population growth rates to $<1$.

\section{Elasticity analyses}

For T. dubius, emergence of seedlings (seed to seedling transition) contributed most to population growth in all treatments (Fig. 7). The annual pathway (seedling to flower to seeds in one growing season) contributed more to population growth than the biennial pathway (seedling to basal rosette to overwintering rosette to flower to seeds) in both shrub-removal and control plots. In contrast, the biennial pathway contributed similarly to the annual pathway in the sheltered treatment (Fig. 7). The annual pathway contributed more to $\lambda$ in the shrub-removal than in the shelter or control treatments (Fig. 7).

For L. serriola, the summer annual pathway (spring seedling to large flowering plant to seeds) contributed more to population growth than the winter annual pathway (seedling to flowering plant to overwintering seedling) in both shrub-removal and sheltered plots (Fig. 8). The contributions of the summer annual pathway were much greater in the shrub-removal treatment than in the sheltered treatment, however (Fig. 8).

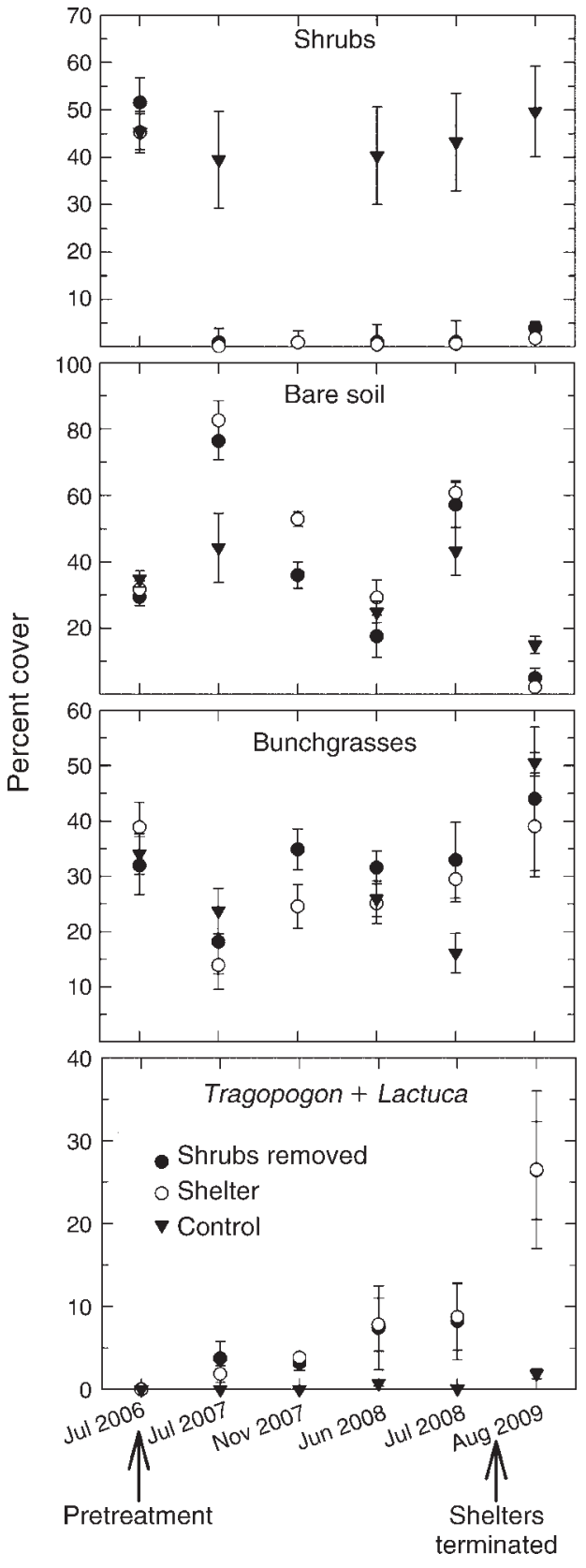

FIG. 5. Cover (mean $\pm \mathrm{SE}$ ) of shrubs, bare soil, bunchgrasses, and exotic forbs before, during, and after the treatment application.

\section{Discussion}

Foundation species strongly influence ecosystem resources and control community dynamics (Ellison et al. 2005). This study indicates that they also can limit exotic plant invasions. The removal of a foundation species, $A$. tridentata, led to short-term increases in $\lambda$ of $T$. dubius and L. serriola over the two years of our study, as we had predicted. Furthermore, $\lambda$ of $T$. dubius was projected to increase beyond initial invasion sizes in shrub-removal plots but not in rainout-shelter plots, where we excluded 


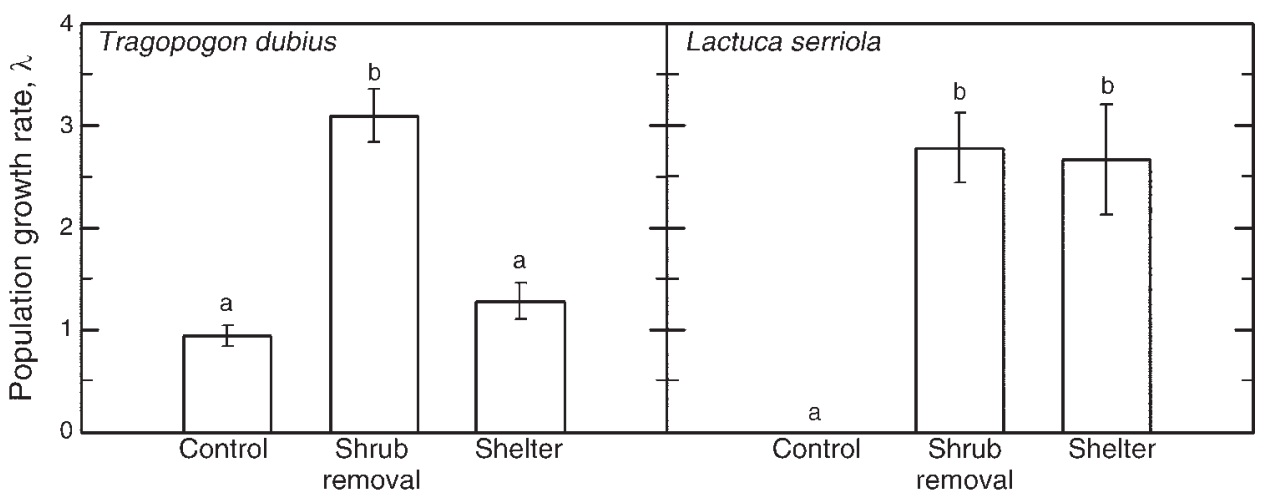

FIG. 6. Population growth rates (mean $\pm \mathrm{SE}$ ) of Tragopogon dubius and Lactuca serriola in control, shrub-removal, and sheltered treatments in 2007 and 2008. Different lowercase letters signify means that are significantly different (randomization tests, $P<0.05)$.

the extra soil water that normally accompanies loss of sagebrush. These findings provide evidence that increased soil water allowed some exotic forbs to successfully grow in areas where sagebrush has been removed. However, $\lambda$ of $L$. serriola was projected to increase in both shrub-removal and sheltered plots, indicating that sagebrush removal had a much stronger positive effect on population growth of this exotic species than could be explained by associated increase in soil water alone.

The life stages that most affected $\lambda$ of $T$. dubius were consistent with our hypothesis. Seedling establishment contributed greatly to $\lambda$ of both species, but probabilities of emergence did not differ appreciably between treatment types (Tables 2 and 3), indicating that observed differences in $\lambda$ resulted from transitions to other life stages. Maturation to flowering was faster and seed production was greater for $T$. dubius in shrubremoval plots than in control or sheltered plots (Fig. 7, Table 2). In both shrub-removal and control treatments, annual plants, which emerged and flowered during a single growing season, contributed more to $\lambda$ than those that overwintered as basal rosettes (Table 2). In 2008, when there were similar amounts of soil water in shrubremoval and control treatments, more $T$. dubius grew as annuals in control plots, and this probably contributed to the importance of the annual pathway in the control treatment. Additionally, survival of $T$. dubius was greater over the summer of 2008 compared to 2007 in control plots, which corresponded with the greater amount of soil water in controls in 2008 (Fig. 4). The responsiveness of $T$. dubius to soil water differences in 2007 and 2008 further implicates the role of soil water availability in the success of this exotic forb. As predicted, seed production of annual plants was important to $\lambda$ of $T$. dubius, especially in the shrubremoval treatment (Fig. 7). Transitions to flowering plant and seed production occurred in late June and early July, when conditions were relatively hot and dry and when soil water is typically limiting. We hypothesize that an increase in soil-water availability allows plants to grow larger and flower sooner, rather than remaining as basal rosettes. Many short-lived forbs need to reach a particular size before they are able to flower (Werner 1975, Gross 1981, Klinkhamer et al. 1987), and they may need sufficient soil-water resources to do so.

Whereas the demography of $T$. dubius was consistent with our hypothesis, the responses of $L$. serriola were only partly consistent. In control plots, L. serriola was scarce and did not survive the seedling stage, but it had high population growth in both shrub-removal and sheltered plots (Table 3, Fig. 6), indicating that the loss of sagebrush, and not necessarily the associated increases in soil water, led to the high population growth we observed. During the first summer of the study, there were few $L$. serriola in the sheltered treatment, but by the following year the number of $L$. serriola increased substantially despite limited soil water (Prevéy et al. 2010). L. serriola may be able to withstand

TABLE 2. Transition probabilities and seed output of the exotic forb Tragopogon dubius in control, shrub-removal, and sheltered treatments over 2007 and 2008.

\begin{tabular}{lccccccccc}
\hline \hline \multicolumn{1}{c}{ Treatment } & $\begin{array}{c}\text { Germination } \\
\left(d_{12}\right)\end{array}$ & $\begin{array}{c}\text { Seedling } \\
\text { to br } \\
\left(b_{11}\right)\end{array}$ & $\begin{array}{c}\text { Seedling } \\
\text { to flower } \\
\left(b_{12}\right)\end{array}$ & $\begin{array}{c}\text { Br to } \\
\text { overwin. } \\
\text { br }\left(c_{11}\right)\end{array}$ & $\begin{array}{c}\text { Seeds per } \\
\text { FP 1 } \\
\left(c_{22}\right)\end{array}$ & $\begin{array}{c}\text { Seeds per } \\
\text { FP 2 } \\
\left(c_{23}\right)\end{array}$ & $\begin{array}{c}\text { Overwin. br } \\
\text { surviving } \\
\text { winter }\left(d_{21}\right)\end{array}$ & $\begin{array}{c}\text { Overwin. br } \\
\text { to flower } \\
\left(b_{32}\right)\end{array}$ & $\lambda$ \\
\hline Control & 0.019 & 0.30 & 0.50 & 0.53 & 68 & 91 & 1 & 1 & $0.94 \pm 0.10$ \\
Shrub removal & 0.020 & 0.40 & 0.57 & 0.62 & 229 & 420 & 0.80 & 0.94 & $3.10 \pm 0.26$ \\
Shelter & 0.015 & 0.56 & 0.32 & 0.67 & 109 & 237 & 0.88 & 0.83 & $1.28 \pm 0.18$
\end{tabular}

Note: Corresponding matrix elements (e.g., $d_{12}$ ) are shown in parentheses in the column headings. Key to abbreviations: br, basal rosette; seeds per FP 1 or FP 2, the average number of seeds per annual (FP 1) or biennial (FP 2) flowering plant in that treatment; $\lambda$, population growth rate $\pm \mathrm{SE}$. 
TABLE 3. Transition probabilities and seed output of Lactuca serriola in control, shrub-removal, and sheltered treatments over 2007 and 2008.

\begin{tabular}{|c|c|c|c|c|c|c|c|c|c|}
\hline Treatment & $\begin{array}{c}\text { Germination } \\
\left(f_{11}\right)\end{array}$ & $\begin{array}{c}\text { Spring sdg } \\
\text { to S FP } \\
\left(b_{11}\right) \\
\end{array}$ & $\begin{array}{c}\text { Spring sdg } \\
\text { to L FP } \\
\left(b_{21}\right) \\
\end{array}$ & $\begin{array}{c}\text { Winter sdg } \\
\text { to S FP } \\
\left(b_{12}\right) \\
\end{array}$ & $\begin{array}{c}\text { Winter sdg } \\
\text { to L FP } \\
\left(b_{22}\right) \\
\end{array}$ & $\begin{array}{c}\text { Seeds per } \\
\text { S FP } \\
\left(c_{11}\right) \\
\end{array}$ & $\begin{array}{c}\text { Seeds per } \\
\text { L FP } \\
\left(c_{12}\right) \\
\end{array}$ & $\begin{array}{c}\text { Winter sdg } \\
\text { surviving } \\
\text { winter }\left(f_{22}\right)\end{array}$ & $\lambda$ \\
\hline$\overline{\text { Control }}$ & & 0 & 0 & 0 & 0 & 0 & 0 & 0 & 0 \\
\hline Shrub removal & 0.015 & 0.06 & 0.19 & 0.13 & 0.13 & 352 & 1602 & 0.16 & $2.78 \pm 0.34$ \\
\hline Shelter & 0.016 & 0.18 & 0.12 & 0.10 & 0.31 & 371 & 1334 & 0.24 & $2.67 \pm 0.54$ \\
\hline
\end{tabular}

Note: Corresponding matrix elements (e.g., $d_{12}$ ) are shown in parentheses in the column headings. Key to abbreviation: sdg, seedling; seeds per S FP or L FP, the average number of seeds per small (S FP) or large (L FP) flowering plant in that treatment; $\lambda$, population growth rate $\pm \mathrm{SE}$.

drier conditions than $T$. dubius because the leaves of $L$. serriola are oriented vertically, which reduces sunlight interception, leaf temperatures, and water stress at midday (Werk and Ehleringer 1985). Additionally, leaves are shed as the flowering stalk elongates (Weaver and Downs 2003), further reducing water loss through stomata. In contrast to shrub-removal and sheltered plots, all $L$. serriola seedlings died by midsummer in control plots. The mortality of $L$. serriola in the control treatment may have resulted from the greater vegetative cover in plots with sagebrush (Prevéy et al. 2010). Microhabitat conditions, such as the amount of bare ground and sagebrush canopy effects on temperature, can be important to the emergence and survival of seedlings (Gross and Werner 1982). Our results indicate that some exotics can invade following removal of dominant competitors, but invasions may not always be attributable to increases in soil resources (LeJeune et al. 2006).

We asked whether consideration of herbivory and seed predation, which were not directly included in the demographic study, could affect our conclusions. $L$. serriola did not experience appreciable herbivory during our study. Although T. dubius experienced herbivory, most plants sustained growth after herbivory events and survived to flower and produce seeds. Seed predation in the shrub-removal treatment would have had to have been $>60 \%$ to change predictions from increasing population growth to decreasing population growth. Thus, herbivory and seed predation probably did not lead to the differences in $\lambda$ in the different treatments.

Predictions from our matrix population models were based on population responses during the first two growing seasons after the removal of sagebrush. We did not attempt to account for competitive interactions of exotic forbs with other herbaceous vegetation, such as bunchgrasses. Bunchgrasses might normally be expected to increase in shrub-removal compared to control plots, but such increases were evident only on one of three sampling events during the years of our population modeling (Fig. 5). Native forbs decreased $50 \%$ in density following shrub removal, from $\sim 2$ to $1 \mathrm{plant} / \mathrm{m}^{2}$ (Prevéy et al. 2010). Nevertheless, the high $\lambda$ predicted for $T$. dubius and L. serriola indicates substantial local increase after sagebrush removal even in the presence of abundant native and exotic bunchgrasses, at least in the short term. Seed quality and germinability were not measured here, but possible differences among treatments would likely contribute to even larger differences in $\lambda$ than we report (Gross and Werner 1982, Roach and Wulff 1987, Breen and Richards 2008). In fall 2009, there was $8 \%$ and up to $20 \%$ less seed dry mass for $T$.
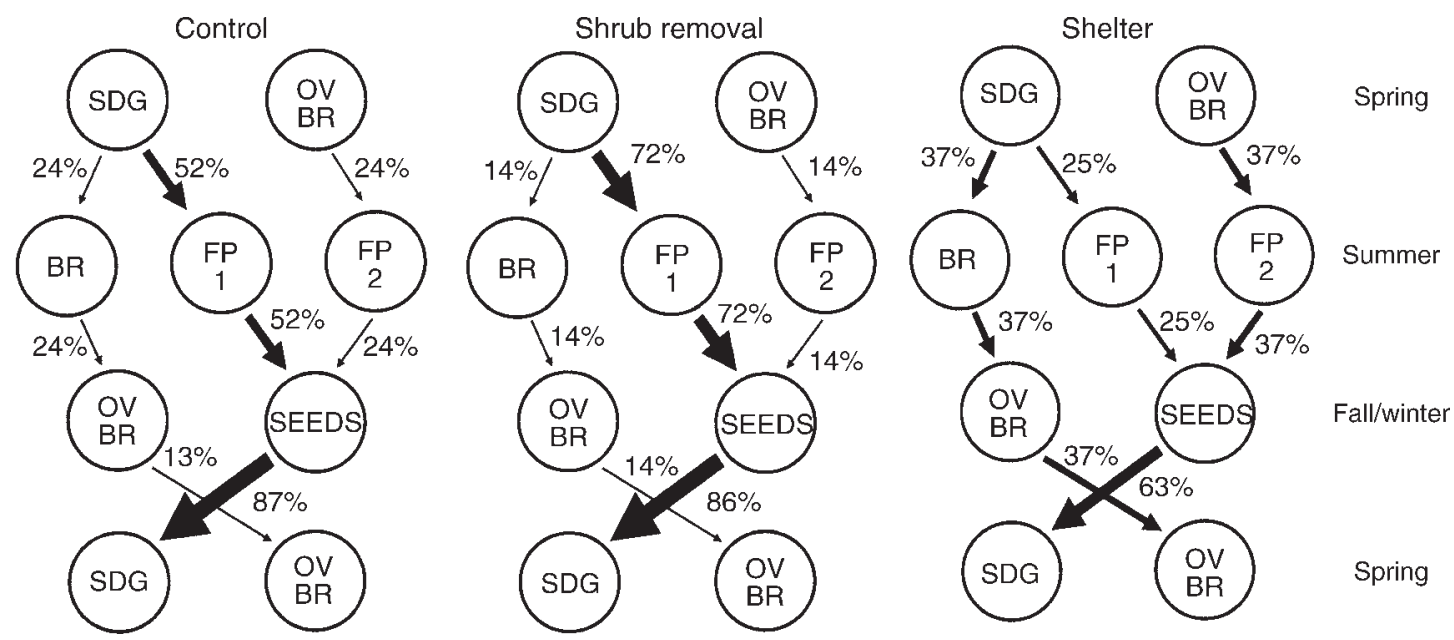

FIG. 7. Elasticities of the population growth rate $(\lambda)$ to proportional changes in the elements of seasonal matrices of Tragopogon dubius in control, shrub-removal, and sheltered treatments (Table 2). Elasticity values were multiplied by 100 to be expressed as percentages. Thicker arrows denote greater elasticities. 

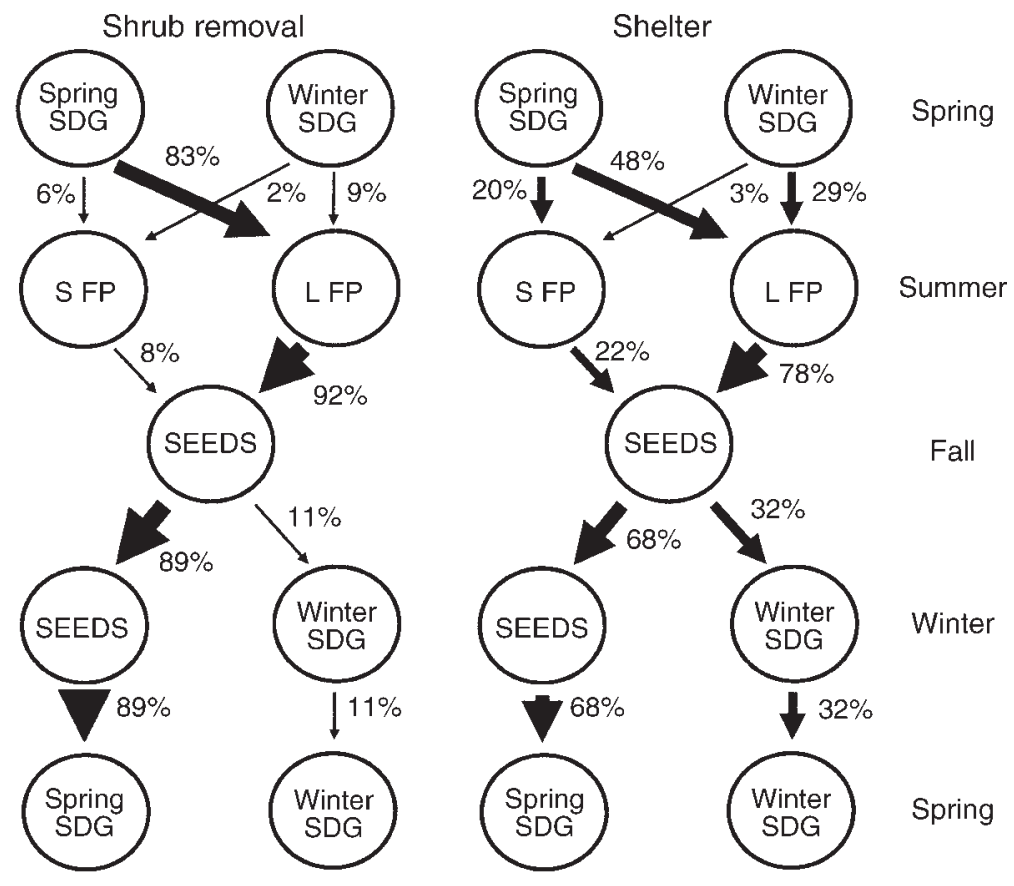

FIG. 8. Elasticities of the population growth rate $(\lambda)$ to proportional changes in the elements of seasonal matrices of Lactuca serriola in control, shrub-removal, and sheltered treatments (Table 3). Elasticity values were multiplied by 100 to be expressed as percentages. Thicker arrows denote greater elasticities.

dubius and L. serriola in undisturbed sagebrush compared to sagebrush-removal plots, respectively, and seed fill was $100 \%$ (L. serriola had no reproduction or viable populations in our control plots; M. Germino, unpublished data). Additionally, T. dubius populations in control plots of undisturbed sagebrush steppe were sink populations, with $\lambda<1$, at least during the two years of our study. This suggests that sagebrush removal may produce local populations of exotic species that serve as sources of propagules that support sink populations, such as $T$. dubius populations in control plots.

Our results suggest that $T$. dubius and $L$. serriola can invade semiarid ecosystems such as sagebrush steppe only when native foundation species are not present. $T$. dubius and L. serriola did not thrive in undisturbed sagebrush steppe, but did establish rapidly increasing populations where native shrubs had been removed. Matrix model projections indicated that populations of T. dubius and L. serriola would decline in control plots. If land use practices and other disturbances do not create conditions that allow establishment and growth of $T$. dubius and L. serriola, these forbs may not be able to survive in sagebrush steppe.

The high $\lambda$ of $T$. dubius in the shrub-removal treatment could also result from a "tap-root advantage" because $T$. dubius may have access to soil water at more depths than native grasses and forbs (Marler et al. 1999, Kulmatiski et al. 2006). Another exotic forb, Centaurea maculosa, may also benefit from this tap-root advantage because its photosynthetic advantages compared to resident grasses in invaded sites appeared linked to a relatively greater supply of water, made possible from its use of deeper-water sources (Hill et al. 2006). Rooting information available for the species we evaluated at our research site are consistent with a deeper-rooting advantage for the exotics compared to grasses that otherwise dominate after fire or shrub removal. Specifically, roots were found to $180 \mathrm{~cm}$ depth under sagebrush and to $50 \mathrm{~cm}$ depth under grasses (other than a trace at $70 \mathrm{~cm}$ ) in root-density maps acquired from a trench separating grass-dominated and sagebrushdominated areas at our research site (Pappani 2004). Also, root mass from 0 to $60 \mathrm{~cm}$ depth was an order of magnitude less in sagebrush-removal compared to control plots, but there was at least 10 -fold more roots in the control plots at depths below $60 \mathrm{~cm}$ (root data from S. Saasa and M. Germino, unpublished, collected on Inouye's [2006] plots at the same site as the present study).

Our data illustrate strong effects of a foundation species, sagebrush, on the available soil water and invasibility of a semiarid ecosystem. Certain species may be more important than overall diversity in influencing community invasibility (Emery and Gross 2007, Thomsen and D'Antonio 2007). Sagebrush removals and promotion of grass-dominated communities are often key elements of management plans for promoting forage or reducing fire risks in sagebrush steppe (Monsen et al. 2004), but our study suggests that these strategies may increase the risk of invasion by exotic, tap-rooted forbs, even where native bunchgrasses or $A$. cristatum are abundant before and after shrub removal. 
Control efforts often focus on the use of herbicides to remove invasive plants, but this strategy by itself can have limited effectiveness in the long term (Rinella et al. 2009). Management strategies aimed at controlling exotic forbs similar to $T$. dubius and $L$. serriola should consider land-use disturbances, loss of foundation species, and corresponding changes in soil resources as causative agents in the invasion of exotics, and focus on conservation and restoration of native communities and characteristic foundation species. Furthermore, the exotic species we studied may be viewed as desirable for forage for domestic and wild ungulates and are commonly not treated or may even be promoted (Monsen et al. 2004), but our study shows a potential invasiveness that may detract from other management goals for the plant community.

\section{ACKNOWLEDGMENTS}

We thank Dennis Demshar, Brandi Burns, Heidi Albano, Stephanie Mathies, Michael-Gene Widmer, Cassidy Michaelis, Sam Purkett, Charley Finley, and Evan Piland for help with field and laboratory work. Richard Inouye assisted in initial experimental layout. Hal Caswell provided valuable insights and consultation on the construction and analysis of matrix models. Peter Murphy assisted with randomization tests. Funding was provided by a USDA NRI grant to Matthew Germino, Nancy Huntly, and others; and NSF grant no. EPS0814387. This material was based on work supported by the National Science Foundation, while working at the Foundation. Any opinion, finding, and conclusions or recommendations expressed in this material are those of the authors and do not necessarily reflect the views of the National Science Foundation.

\section{Literature Cited}

Breen, A. N., and J. H. Richards. 2008. Irrigation and fertilization effects on seed number, size, germination and seedling growth: implications for desert shrub establishment. Oecologia 157:13-19.

Caldwell, M. 1985. Cold desert. Pages 198-212 in B. F. Chabot and H. A. Mooney, editors. Physiological ecology of North American plant communities. Chapman and Hall, New York, New York, USA.

Caswell, H. 2001. Matrix population models: construction, analysis, and interpretation. Second edition. Sinauer Associates, Sunderland, Massachusetts, USA.

Caswell, H., and M. C. Trevisan. 1994. Sensitivity analysis of periodic matrix models. Ecology 75:1299-1303.

Chambers, J. C., B. A. Roundy, R. R. Blank, S. E. Meyer, and A. Whittaker. 2007. What makes Great Basin sagebrush ecosystems invasible by Bromus tectorum? Ecological Monographs 77:117-145.

Chambers, J. C., and M. J. Wisdom. 2009. Research and management issues associated with land cover and land use change in the Great Basin. Restoration Ecology 17:707-714.

Clements, D. R., M. K. Upadhyaya, and S. J. Bos. 1999. The biology of Canadian weeds. 110. Tragopogon dubius Scop., Tragopogon pratensis L., and Tragopogon porrifolius L. Canadian Journal of Plant Science 79:153-163.

Cook, C. W., and C. E. Lewis. 1963. Competition between big sagebrush and seeded grasses on foothill ranges in Utah. Journal of Range Management 16:245-249.

Daehler, C. 2003. Performance comparisons of co-occurring native and alien invasive plants: implications for conservation and restoration. 2003. Annual Review of Ecology and Evolutionary Systematics 34:183-211.
D'Antonio, C. M. 2000. Fire, plant invasions, and global changes. Pages 65-93 in H. A. Mooney and R. J. Hobbs, editors. Invasive species in a changing world. Island Press, Washington, D.C., USA.

D'Antonio, C. M., and P. M. Vitousek. 1992. Biological invasions by exotic grasses, the grass/fire cycle, and global change. Annual Review of Ecology and Systematics 23:6387.

Davies, K. W., T. J. Svejcar, and J. D. Bates. 2009. Interaction of historical and nonhistorical disturbances maintains native plant communities. Ecological Applications 19:1536-1545.

Davis, A. S., D. A. Landis, V. Nuzzo, B. Blossey, E. Gerber, and H. L. Hinz. 2006. Demographic models inform selection of biocontrol agents for garlic mustard (Allaria petiolata). Ecological Applications 16:2399-2410.

Davis, M. A., J. P. Grime, and K. Thompson. 2000. Fluctuating resources in plant communities: a general theory of invasibility. Journal of Ecology 88:528-534.

Dobrowolski, J. P., M. M. Caldwell, and J. H. Richards. 1990. Basin hydrology and plant root systems. Pages 243-292 in C. B. Osmond, L. F. Pitelka, and G. M. Hidy, editors. Plant biology of the basin and range. Ecological Studies Volume 80. Springer, Berlin, Germany.

Ellison, A. M., et al. 2005. Loss of foundation species: consequences for the structure and dynamics of forested ecosystems. Frontiers in Ecology and the Environment 3: 479-486.

Emery, S. M., and K. L. Gross. 2005. Effects of timing of prescribed fire on the demography of an invasive plant, spotted knapweed Centaurea maculosa. Journal of Ecology 42:60-69.

Emery, S. M., and K. L. Gross. 2007. Dominant species identity, not community evenness, regulates invasion in experimental grassland plant communities. Ecology 88:954964.

Gross, K. L. 1981. Predictions of fate from rosette size in four "biennial" plant species: Verbascum thapsus, Oenothera biennis, Daucus carota, and Tragopogon dubius. Oecologia 48:209-213.

Gross, K. L., and P. A. Werner. 1982. Colonizing abilities of "biennial" plant species in relation to ground cover: implications for their distributions in a successional sere. Ecology 63:921-931.

Hadley, N. F., and S. R. Szarek. 1981. Productivity of desert ecosystems. BioScience 31:747-753.

Harper, J. L. 1977. Population biology of plants. Academic Press, New York, New York, USA.

Hill, J. P., M. J. Germino, J. M. Wraith, B. E. Olson, and M. B. Swan. 2006. Advantages in water relations contribute to greater photosynthesis in Centarea maculosa compared with established grasses. International Journal of Plant Sciences 167:269-277.

Hitchcock, C. L., and A. Cronquist. 1973. Flora of the Pacific Northwest. University of Washington Press, Seattle, Washington, USA.

Holmgren, M., et al. 2006. Extreme climatic events shape arid and semiarid ecosystems. Frontiers in Ecology and the Environment 2:87-95.

Hood, G. M. 2008. PopTools version 3.0.6. 〈http://www.cse. csiro.au/poptools $\rangle$

Horvitz, C. C., and D. W. Schemske. 1995. Spatiotemporal variation in demographic transitions of a tropical understory herb: projection matrix analysis. Ecological Monographs 65: 155-192.

Inouye, R. S. 2006. Effects of shrub removal and nitrogen addition on soil moisture in sagebrush steppe. Journal of Arid Environments 65:604-618.

Jackson, L. E. 1995. Root architecture in cultivated and wild lettuce (Lactuca spp.). Plant, Cell and Environment 18:885894. 
Karban, R. 2007. Associational resistance for mule's ears with sagebrush neighbors. Plant Ecology 191:295-303.

Keeley, J. E. 2006. Fire management impacts on invasive plants in the western United States. Conservation Biology 20:375384.

Klinkhamer, P. G., T. J. de Jong, and E. Meelis. 1987. Lifehistory variation and the control of flowering in short-lived monocarps. Oikos 49:309-314.

Kulmatiski, A. 2006. Exotic plants establish persistent communities. Plant Ecology 187:261-275.

Kulmatiski, A., K. H. Beard, and J. M. Stark. 2006. Exotic plant communities shift water-use timing in a shrub-steppe ecosystem. Plant and Soil 288:271-284.

LeJeune, K. D., K. N. Suding, and T. R. Seastedt. 2006. Nutrient availability does not explain invasion and dominance of a mixed grass prairie by the exotic for Centaurea diffusa Lam. Applied Soil Ecology 32:98-110.

Leonard, K.M., K. P. Reese, and J. W. Connelly. 2000. Distribution, movements, and habitat of sagegrouse (Centrocercus urophasianus) on the Upper Snake River Plain of Idaho: changes from the 1950s to 1990s. Wildlife Biology 6: 265-270.

Lucas, R. W., I. N. Forseth, and B. B. Casper. 2008. Using rainout shelters to evaluate climate change effects on the demography of Cryptantha flava. Journal of Ecology 96:514522.

Maestre, F. T., J. F. Reynolds, E. Huber-Sannwald, J. Herrick, and M. Stafford Smith. 2006. Understanding global desertification: biophysical and socioeconomic dimensions of hydrology. Pages 315-329 in P. D'Odorico and A. Porpororato, editors. Dryland ecohydrology. Springer, Dordrecht, The Netherlands.

Marks, M. K., and S. D. Prince. 1982. Seed physiology and seasonal emergence of wild lettuce Lactuca serriola. Oikos 38: 242-249.

Marler, M. J., C. A. Zabinski, T. Wojtowicz, and R. M. Callaway. 1999. Mycorrhizae and fine root dynamics of Centaurea maculosa and native bunchgrasses in western Montana. Northwest Science 73:217-223.

McGinley, M. A. 1989. Within and among plant variation in seed mass and pappus size in Tragopogon dubius. Canadian Journal of Botany 67:1298-1304.

McGrath, C. L. 1987. Soil survey of Bannock County area, Idaho. USDA Natural Resources Conservation Service, Washington, D.C., USA.

Meiqin, Q., and M. K. Upadhyaya. 1993. Seed germination ecophysiology of meadow salsify (Tragopogon pratensis) and western salsify (T. dubius). Weed Science 41:362-368.

Monsen, S. B., R. Stevens, and N. L. Shaw. 2004. Restoring western ranges and wildlands. USDA Forest Service, General Technical Report RMRS-GTR-136, Volume 1. Ft. Collins, Colorado, USA.

Noss, R. F., E. T. LaRoe III, and J. M. Scott. 1995. Endangered ecosystems of the United States: a preliminary assessment of loss and degradation. Biological Report 28. National Biological Service, Washington, D.C., USA.

Noy-Meir, I. 1973. Desert ecosystems: environment and producers. Annual Review of Ecology and Systematics 4: 25-51.

Pappani, K. 2004. Water relations of a sagebrush steppe community: performance of Stipa comata (needle and thread grass) and Agropyron dasytachum (thick-spiked wheatgrass). Thesis. Idaho State University, Pocatello, Idaho, USA.

Pardini, E. A., J. M. Drake, J. M. Chase, and T. M. Knight. 2009. Complex population dynamics and control of the invasive biennial Alliaria petiolata (garlic mustard). Ecological Applications 19:387-397.

Parker, I. M. 2000. Invasion dynamics of Cytisus scoparius: a matrix model approach. Ecological Applications 10:726-743.
Prevéy, J. S., M. J. Germino, N. J. Huntly, and R. S. Inouye. 2010. Exotic plants increase and native plants decrease with loss of foundation species in sagebrush steppe. Plant Ecology 207:39-49.

Prince, S. D., M. K. Marks, and R. N. Carter. 1978. Induction of flowering in wild lettuce (Lactuca serriola L.) I. Vernalization. New Phytologist 81:265-277.

Reichman, O. J., and S. C. Smith. 1991. Responses to simulated leaf and root herbivory by a biennial, Tragopogon dubius. Ecology 72:116-124.

Rinella, M. J., B. D. Maxwell, P. K. Fay, T. Weaver, and R. L. Sheley. 2009. Control effort exacerbates invasive-species problem. Ecological Applications 19:155-162.

Roach, D. A., and R. D. Wulff. 1987. Maternal effects in plants. Annual Review of Ecology and Systematics 18:209235.

SAS Institute. 2002-2003. SAS version 9.1.3. SAS Institute, Cary, North Carolina, USA.

Shea, K., and P. Chesson. 2002. Community ecology theory as a framework for biological invasions. Trends in Ecology and Evolution 17:170-176.

Shea, K., and D. Kelly. 1998. Estimating biocontrol agent impact with matrix models: Carduus nutans in New Zealand. Ecological Applications 8:824-832.

Smith, M., H. Caswell, and P. Mettler-Cherry. 2005. Stochastic flood and precipitation regimes and the population dynamics of a threatened floodplain plant. Ecological Applications 15: $1036-1052$.

Smith, S. D., R. K. Monson, and J. E. Anderson. 1997. Case study: Artemisia tridentata. Pages 75-93 in Physiological ecology of North American desert plants. Springer-Verlag, Berlin, Germany.

Sturges, D. L. 1973. Soil moisture response to spraying big sagebrush the year of treatment. Journal of Range Management 26:444-447.

Stylinski, C. D., and E. B. Allen. 1999. Lack of native species recovery following severe exotic disturbance in southern Californian shrublands. Journal of Applied Ecology 36:544554.

Thomsen, M. A., and C. M. D'Antonio. 2007. Mechanisms of resistance to invasion in a California grassland: the roles of competitor identity, resource availability, and environmental gradients. Oikos 116:17-30.

USDA, NRCS. 2008. The PLANTS database. National Plant Data Center, Baton Rouge, Louisiana, USA. 〈http://plants. usda.gov $\rangle$

Weaver, S. E., and M. P. Downs. 2003. The biology of Canadian weeds. 122. Lactuca serriola L. Canadian Journal of Plant Science. 83:619-628.

Welch, B. L. 2005. Big sagebrush: a sea fragmented into lakes, ponds, and puddles. USDA Forest Service General Technical Report RMRSGTR-144.

Werk, K. S., and J. Ehleringer. 1985. Photosynthetic characteristics of Lactuca serriola L. Plant, Cell and Environment 8: 345-350.

Werner, P. A. 1975. Predictions of fate from rosette size in teasel (Dipsacus fullonum L.). Oecologia 20:197-201.

Werner, P. A., and H. Caswell. 1977. Population growth rates and age vs. stage distribution for teasel (Dipsacus sylvestris Huds.). Ecology 58:1103-1111.

Whisenant, S. G. 1990. Changing fire frequencies on Idaho's Snake River Plains: ecological and management implications. Pages 4-10 in E. D. McArthur, E. M. Romney, S. D. Smith, and P. T. Tueller, editors. Proceedings - symposium on cheatgrass invasion, shrub die-off, and other aspects of shrub ecology and management. Intermountain Research Station, Ogden, Utah, USA.

Whitson, T. D., editor. 2000. Weeds of the west. Grand Teton Lithography, Jackson, Wyoming, USA. 